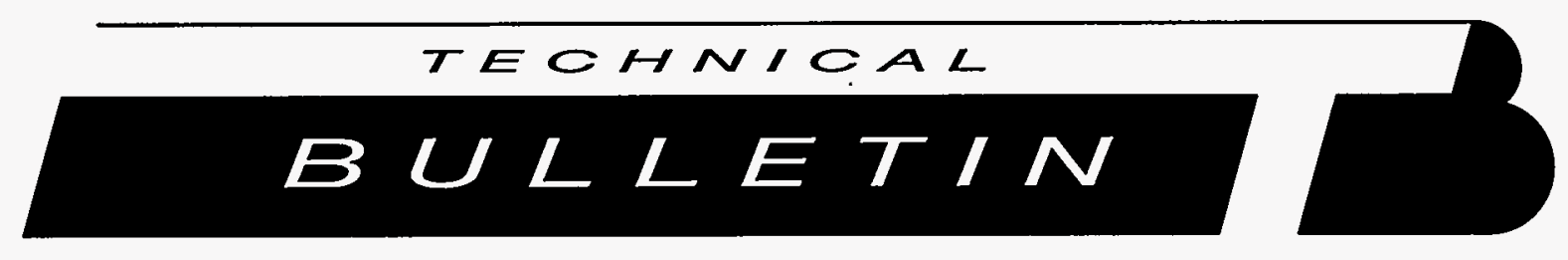

1991

National Low-Level Waste Management Program Technical Bulletins provide information to States, compact regions, and other interested parties on issues related to the development of low-level radioactive waste disposal facilities. The Bulletins distribute information that is of immediate concern to the States and regions or that is not suited to more formal reports. Technical Bulletins are published on an as-needed basis.

The intent of this Technical Bulletin is to provide a basic understanding of the performance assessment process for the evaluation of near-surface low-level radioactive waste disposal facilities. Regulatory guidance for performance assessment will be discussed as well as the various approaches and principles involved in determining compliance with the defined performance objectives.

\title{
PERFORMANCE ASSESSMENTS FOR NEAR-SURFACE LOW-LEVEL RADIOACTIVE WASTE DISPOSAL FACILITIES
}

\author{
Kevin M. Kostelnik \\ Idaho National Engineering Laboratory \\ EG\&G Idaho, Inc.
}

\section{Introduction}

The Low-Level Radioactive Waste Policy Act (PL 96-573) of December 1980 delegated responsibility for the disposal of commercially generated low-level radioactive wastes (LLW) to the States. A State could either develop its own disposal facility for the LLW generated within its borders or it could enter into a compact with other States and establish a regional disposal facility for the LLW generated within that region.

The Low-Level Radioactive Waste Policy Amendments Act of 1985 (PL 99-240) established a series of milestones to ensure that the national compact system for LLW disposal progressed as scheduled. One milestone is the submission of a complete license application for LLW disposal by January 1, 1992 (Brown, 1986;
PL 99-240). License applications are required to provide a reasonable assessment of potential radioactive releases via the most significant transport mechanisms for each institutional phase of the facility (NRC, 1988a). Performance assessment calculations are intended to show that the proposed near-surface disposal facility is capable of operating within the performance objectives defined in Title 10 of the Code of Federal Regulations Part 61 (10 CFR 61). This regulation emphasizes the need to maintain releases of radioactivity as low as reasonably achievable. Low-level radioactive waste disposal facilities must be designed, operated, and eventually closed in a manner that ensures long-term stability and protects public health and safety. These requirements are to provide the public with reasonable assurances of limited human exposure.

\section{MASTER}

DISTRIBUTION OF THIS DOCUIAENT IS LRILLMTED 


\section{Performance Objectives}

Performance objectives have been defined in 10 CFR 61 for the protection of the public health, safety, and environmental resources. These performance objectives require:

- Protection of the general population from releases of radioactive material by requiring that annual dose equivalents not exceed $25 \mathrm{mrem} / \mathrm{yr}$ to the whole body, $75 \mathrm{mrem} / \mathrm{yr}$ to the thyroid, or $25 \mathrm{mrem} / \mathrm{yr}$ to any other organ of any member of the public [10 CFR 61.41]

- Protection of individuals from inadvertent intrusion [10 CFR 61.42]

- Protection of individuals during operation [10 CFR 61.43]

- Stability of the site after closure [10 CFR 61.44].

The disposal facility must be sited, designed, operated, and closed to achieve long-term stability, eliminate active maintenance following closure, and ensure protection of inadvertent intruders.

\section{Definition of Performance Assessment}

Performance assessment of a LLW disposal facility is a systematic analysis of the disposal facility and its surrounding environment, with the intent of demonstrating compliance with the radiological performance objectives established by 10 CFR 61 to protect the public and inadvertent intruders (Case and Otis, 1988). Defensible performance assessment calculations are a vital part of a complete license application for a LLW disposal facility (NRC, 1988a). Present conditions and future scenarios must be considered and should be evaluated for at least a 500-year time frame. Performance assessments should be performed so that reasonable extrapolations for time periods greater than 500 years can be made to demonstrate that maximum dose rates will not ex- ceed regulatory limits. Performance assessments may also be used to establish site-specific inventory limits for certain nuclides of concern.

The goal of a performance assessment for a near-surface LLW disposal facility is to calculate potential radiological impacts for each of the human exposure pathways (NRC, 1988a). This involves determining potential pathways and specific receptor locations for human exposure to radionuclides; developing appropriate scenarios for each of the institutional phases of a disposal facility; and maintaining quality assurance and control of all data, computer codes, and documentation.

\section{The Performance Assessment Process}

A proposed facility's performance objectives must be defined prior to conducting a performance assessment. For non-Agreement States, these objectives are defined in 10 CFR 61. Agreement States have assumed regulatory responsibility from the U.S. Nuclear Regulatory Commission (NRC), in accordance with the Atomic Energy Act, for disposing of LLW within their borders. The aforementioned performance objectives are the minimum requirements. Additional requirements compatible with NRC regulations may be added by State regulations.

Site-specific data obtained through site characterization studies are the most limiting and costly aspect of the performance assessment process. Performance assessment data requirements include: waste characteristics such as activity, volumes, composition, and physical and chemical form; facility characteristics such as size and type of disposal facility; disposal procedures including package integrity and stabilization techniques; biotic considerations such as the composition and abundance of plant and animal communities; and environmental factors including meteorological, geochemical, hydrological, and geologic characteristics (Case and Otis, 1988; National Low-Level Waste Management Program, 1990).

Development of potential exposure scenarios is an important part of modeling the disposal 
system and should be initiated during the site characterization phase. Although typical scenarios are presented in the U.S. Nuclear Regulatory Commission's Standard Format and Content of a License Application for a Low-Level Radioactive Waste Disposal Facility (NUREG 1199, Rev. 1), site-specific scenarios must also be considered. The most relevant exposure scenarios must then be expanded for each of the facility's institutional phases to form a simple descriptive representation (conceptual model) of the disposal facility (Starmer, 1988; Starmer et al., 1988).

Conceptual models should adequately address all aspects of the system without undue complexity (Kozak et al., 1990). Conceptual models of a near-surface LLW disposal system should include: (a) a facility or near-field model to describe the release of radionuclides within the facility, (b) a flow/transport model to describe the movement of radionuclides, (c) a demographic model to show the spatial distribution of the human population around the disposal facility, and (d) an exposure model to describe which, and how, receptors become exposed (Case et al., 1989). Particular attention should be paid to the most significant site-specific pathway. Conceptual models must eventually be translated into mathematical equations and mathematical models to simulate each process.

Mathematical modeling usually involves screening calculations and may require additional data collection to determine the potential for compliance with the defined performance objectives. Mathematical equations and models are generally written as computer code for detailed pathway analyses. The use of existing and established code, if applicable to a specific site, is generally recommended over the development of site-specific code for each disposal facility, thereby permitting a comparison of the assessment results during the review and verification process. Final code selection should ultimately be governed by the identified pathways, sitespecific processes, and code capabilities.

Once an appropriate code has been selected, performance assessment calculations should begin. An iterative approach should be employed to improve the analysis. Uncertainties are introduced throughout the entire performance assessment process (Bonano and Cranwell, 1988; Maheras and Kotecki, 1990). Performance assessment calculations, therefore, should not be viewed as absolute. Uncertainty associated with input data leads to uncertainty in the output (parameter uncertainty). Uncertainty is inherent when predicting future events and processes (scenario uncertainty). Translating the subjective conceptual models into mathematical codes introduces additional uncertainty (modeling uncertainty) because mathematical descriptions will necessarily include various assumptions. An uncertainty analysis should be performed to quantify the inherent confidence of the calculated results.

A sensitivity analysis is a quantitative measure of the effect input parameters have upon the calculated results (Maheras and Kotecki, 1990; Seitz et al., 1990). Various analytical techniques exist as discussed in Maheras and Kotecki. Those individual parameters exhibiting the greatest influence on the model are considered the most sensitive (Case et al., 1988). Sensitivity and uncertainty analyses are important for identifying data variability and deficiencies. Resources should then be directed to parameters identified as being the most sensitive and uncertain.

Although performance assessment results are likely to be conservative values, their intent is to demonstrate the projected performance level for the LLW disposal facility. An active public information program should be employed to educate the public in both LLW disposal and the entire performance assessment process. Various concerns of the public, the technical community, and the site regulators must be adequately addressed by a performance assessment.

Throughout the performance assessment process, varying degrees of data and expertise will be required. Initial calculations should identify possible data deficiencies or conceptual problems. Because of the tremendous interactions among the many phases of performance assessment, some flexibility must be maintained throughout the overall process. An iterative approach should be employed to improve and refine performance 
assessment methods and results. A thorough quality assurance (QA) program should also be established and maintained throughout the performance assessment process (NRC, 1988a). This QA program should provide guidance for collecting, managing, and analyzing data as well as for documenting procedures and analyses (NRC, 1988a). Seitz et al. provides guidance for testing, verifying, and validating performance assessment software.

\section{Performance Assessment Computer Codes}

Performance assessment codes that are capable of simulating the most critical exposure pathways for the proposed LLW disposal facility should be chosen. Generally, a single code will not be capable of adequately modeling all scenarios or pathways. To address a variety of exposure scenarios, several codes should be used.

Performance assessment codes are often differentiated according to their specific capabilities (Case et al., 1989). For example, performance assessment codes are often categorized as either process-level or system-level codes. Processlevel codes are specialized codes dealing with a particular component of the disposal system, while the more generalized system-level codes integrate several processes involved in the system. Process-level codes generally predict a given behavior on a mechanistic basis. Processlevel codes often use multidimensional models and may therefore be somewhat complex. Sitespecific environmental data are required to produce the more realistic and less conservative results. Such processes as infiltration, container degradation, flow and transport in saturated and unsaturated zones, which are extremely difficult to represent, are routinely modeled with processlevel codes. Examples of codes in this category include HELP (Schroeder et al., 1984), BLT (Suen and Sullivan, 1990), PORFLO (Runchal et al., 1985), and UNSAT-H (Fayer and Jones, 1990).

System-level codes incorporate multiple subtasks such as source term determinations, exposure pathways, and transport mechanisms.
Results from system-level codes are generally more conservative than their process-level counterparts. Examples of system-level codes include PATHRAE (Rogers and Hung, 1987a) and PRESTO-CPG (Rogers and Hung, 1987b).

The NRC will review non-Agreement States' license applications and will assess their compliance with the performance objectives of 10 CFR 61. To that end, the NRC has developed a performance assessment methodology for its confirmatory review of license applications (Kozak et al., 1990). Within this methodology, the NRC has reviewed and recommended a number of codes useful in the performance assessment process (Kozak et al., 1989a, b, c; Shipers, 1889a, b).

\section{Modeling Approach}

Different levels of performance assessment modeling are required for the evaluation of a LLW disposal facility (Starmer et al., 1988). Initially, a system-level approach can provide a conservative approximation of the performance of a proposed LLW disposal facility. This initial modeling effort would be useful during the site selection and site characterization phases of the siting process, when less site-specific data will be available. This initial level will be useful in evaluating the disposal concepts and methodology and will thereby provide guidance for the remaining data collection effort.

A more data-intensive modeling effort may eventually be necessary to fully understand the various disposal system components (Starmer et al., 1988). Specific process-level codes are useful during this phase because of the complexity of the various pathways. For example, threedimensional groundwater codes may be necessary to accurately characterize the hydrologic portion of the system.

Performance assessment calculations included in a license application should be conservative yet defensible (Starmer, 1988; Starmer et al., 1988). The simplest model that adequately represents the system should be used when applying for a LLW disposal license. 


\section{Review of Performance Assessments}

Demonstration of regulatory compliance is the license applicant's responsibility (NRC, 1988b). The NRC or the appropriate Agreement State agency will review performance assessments to determine the adequacy of regulatory compliance for the proposed facility. The NRC provides guidance on their performance assessment review process in Standard Review Plan for Review of a License Application for a Low-Level Radioactive Waste Disposal Facility (NUREG 1200, Rev. 1). An NRC review will determine if the physical system and scenarios were defined properly and represented correctly with appropriate models. Performance assessment calculations will also be evaluated and may be verified by the NRC. Agreement States may make use of these NRC documents as guidance in addition to material related to State-specific requirements.

\section{Summary}

The goal of a performance assessment for a LLW disposal facility is to determine the proposed facility's projected compliance with regulatory limits in terms of doses to the general public and to protect inadvertent intruders. A set of exposure scenarios must be evaluated for each of the various institutional phases of the facility; a quantitative evaluation must be performed for the most probable scenarios.

Evaluation of the final conceptual model of the facility and site should involve the use of appropriate computer code and site-specific data. Code selection for a performance assessment should be based on code capabilities as well as on site- specific needs and characteristics. Generally, a single code will not be capable of simulating all relevant scenarios. Various levels of modeling are necessary to fully evaluate the performance of each LLW disposal facility. During site characterization, a lack of sufficient data forces the establishment of various assumptions. At this preliminary stage, system-level codes are useful for bounding estimates of system performance. As data collection progresses, more specific process-level codes should be used to provide greater understanding of specific pathways and components. Using several codes and coupling various models together provide a more comprehensible evaluation of the various complex processes associated with LLW disposal facilities. The final calculations used in support of a license application must be defensible. Therefore, the simplest code that accurately and adequately simulates the system should be used.

A review of performance assessments for confirmation of regulatory compliance will be conducted by the NRC or the appropriate Agreement State regulatory agency. The license applicant is responsible for demonstrating compliance and must provide sufficient information to permit an independent review of the assessment.

Performance assessment codes are tools for evaluating a proposed LLW disposal facility's regulatory compliance. This evaluation should objectively assess the physical properties of the facility and its environment. Calculations in support of this evaluation must be conservative yet realistic and they must also be technically defensible and supported by adequate data.

\section{DISCLAIMER}

This document was prepared as an account of work sponsored by an agency of the United States Government. Reference herein to any specific commercial product, process, or service by trade name, trademark, manufacturer, or otherwise, does not necessarily constitute or imply its endorsement, recommendation, or favoring by the United States Government or any agency thereof. The views and opinions of authors expressed herein do not necessarily state or reflect those of the United States Government or any agency thereof. 


\section{References}

Bonano, E.J. and R.W. Cranwell, "Treatment of Uncertainties in the Performance Assessment of Geologic High-Level Radioactive Waste Repositories," Mathematical Geology, Vol. 20, No. 5, 1988.

Brown, H., "The Low-Level Waste Handbook: A User's Guide to the Low Level Radioactive Waste Policy Amendments Act of 1985," National Governors' Association Center for Policy Research, 1986.

Case, M.J., S.J. Maheras, M.D. Otis, and R.G. Baca, A Review and Selection of Computer Codes for Establishment of the Performance Assessment Center, DOE/LLW-83, U.S. Department of Energy, July 1989.

Case, M.J. and M.D. Otis, Guidelines for Radiological Performance Assessment of DOE Low-Level Radioactive Waste Disposal Sites, DOE/LLW-62T, U.S. Department of Energy, 1988.

Code of Federal Regulations, Title 10, Part 61, "Licensing Requirements for Land Disposal of Radioactive Waste," Office of the Federal Register, January 1983.

Fayer, M.J. and T.L. Jones, UNSAT-H Version 2.0: Unsaturated Soil Water and Heat Flow Model, PNL-6779, U.S. Department of Energy, April 1990.

Kozak, M.W., C.P. Harlan, M.S.Y. Chu, B.L. O'Neal, C.D. Updegraff, and P.A. Mattingly, Background Information for the Development of a Low-Level Waste Performance Assessment Methodology, Selection and Integration of Models, NUREG/CR-5453 Vol. 3, U.S. Nuclear Regulatory Commission, December 1989a.

Kozak, M.W., M.S.Y. Chu, C.P. Harlan, and P.A. Mattingly, Background Information for the Development of a Low-Level Waste Performance Assessment Methodology, Identification and Recommendation of Computer Codes, NUREG/CR-5453, Vol. 4, U.S. Nuclear Regulatory Commission, December 1989b.

Kozak, M.W., M.S.Y. Chu, P.A. Mattingly, J.D. Johnson, and J.T. McCord, Background Information for the Development of a Low-Level Waste Performance Assessment Methodology, Computer Code Implementation and Assessment, NUREG/CR-5453, Vol. 5, U.S. Nuclear Regulatory Commission, December 1989c.

Kozak, M.W., M.S.Y. Chu, and P.A. Mattingly, A Performance Assessment Methodology for Low-Level Waste Facilities, NUREG/CR-5532, U.S. Nuclear Regulatory Commission, July 1990.

Maheras, S.J. and M.R. Kotecki, Guidelines for Sensitivity and Uncertainty Analyses of Low-Level Radioactive Waste Performance Assessment Computer Codes, DOE/LLW-100, U.S. Department of Energy, September 1990.

National Low-Level Waste Management Program, Low-Level Waste Management Handbook Series, Environmental Monitoring for Low-Level Waste Disposal Sites, DOE/LLW-13Tg Rev. 2, U.S. Department of Energy, February 1990.

Low-Level Radioactive Waste Policy Act, Public Law 96-573, December 1980.

Low-Level Radioactive Waste Policy Amendments Act of 1985, Public Law 99-240, January 1986.

Rogers, V. and C. Hung, PATHRAE-EPA: A Low-Level Radioactive Waste Environmental Transport and Risk Assessment Code, Methodology and Users Manual, EPA 520/1-87-028, U.S. Environmental Protection Agency, December 1987a. 
Rogers, V. and C. Hung, PRESTO-EPA-CPG: A Low-Level Radioactive Waste Environmental Transport and Risk Assessment Code, Methodology and Users Manual, EPA 520/1-87-026, U.S. Environmental Protection Agency, December 1987b.

Runchal, A.K., B. Sagar, R.G. Baca, and N.W. Kline, PORFLO - A Continuum Model for Fluid Flow, Heat Transfer, and Mass Transport in Porous Media, Model Theory, Numerical Methods, and Computational Tests, RHO-BW-CR-150 P, U.S. Department of Energy, September 1985.

Schroeder, P.R., J.M. Morgan, T.M. Walski, and A.C. Gibson, Hydrologic Evaluation of Landfill Performance (HELP) Model: Volume 1, User's Guide for Version 1, EPA/530-SW-84-009, U.S. Environmental Protection Agency, June 1984.

Seitz, R.R., S.D. Matthews, and K.M. Kostelnik, Guidelines for Acquisition, Installation, and Testing of Performance Assessment Software, DOE/LLW-102, U.S. Department of Energy, September 1990.

Shipers, L.R., Background Information for the Development of a Low-Level Waste Performance Assessment Methodology, Identification of Potential Exposure Pathways, NUREG/CR-5453, Vol. 1, U.S. Nuclear Regulatory Commission, December 1989a.

Shipers, L.R. and C.P. Harlan, Background Information for the Development of a Low-Level Waste Performance Assessment Methodology, Assessment of Relative Significance of Migration and Exposure Pathways, NUREG/CR-5453, Vol 2, U.S. Nuclear Regulatory Commission, December 1989b.

Starmer, R. J., “Overview of Performance Assessment for Low-Level Waste Disposal Sites," paper presented at the Technical Coordinating Committee Performance Assessment Workshop, El Paso, Texas, November $29-30,1988$.

Starmer, R.J., L.G. Deering, and M.F. Weber, "Performance Assessment Strategy for Low-Level Waste Disposal Sites," in Proceedings, Tenth Annual DOE Low-Level Waste Management Conference, Denver, Colorado, August 30 - September 1, 1988.

Suen, C.J. and T.M. Sullivan, "BLT: A Source Term Computer Code for Low-Level Waste Shallow Land Burial," Conference on Waste Management '90, Tucson, Arizona, February 25 - March 1, 1990.

U.S. Nuclear Regulatory Commission, Standard Format and Content of a License Application for a Low-Level Radioactive Waste Disposal Facility, NUREG 1199, Rev.1, January 1988a.

U.S. Nuclear Regulatory Commission, Standard Review Plan for the Review of a License Application for a Low-Level Radioactive Waste Disposal Facility, NUREG 1200, Rev.1, January 1988b. 
